\title{
RAGNAR FRISCH'S ROLE IN ECONOMETRICS
}

\author{
A sketch
}

\section{Jan TINBERGEN}

Hatiklaan, The Hague, The Netherlands

The foremost place of $\mathbf{R}$. Frisch in the modern development of economics and especially econometrics is assessed. Some of his achievements are briefly described: on land rent theory, marginal utility of income, bunch map 'technique' model building, planning, programming and Pareto optima. Sonie remarkable facts of Frisch's life are also reported, e.g. his short stay in a concentration camp during the war and his crusade against Norway joinirg the E.E.C. on the ground that the country had better remain an outside exampie of democracy and social justice.

Econometrics has suffered a severe loss: its inspiring leäder for decades, Ragnar Frisch, has passed away. As a token of my admiration and friendship for him let me try to give a sketch of his impressively fruitful scientific activity - with a few personal recollections added.

When in 1930 in the United States and in 1931 in Europe the Econometric Society was founded, Frisch was among the pioneers. It was a matter of course that he would be the editor of the sociely's journal Eccnometrica, a 'post' he held for twenty-one years. I $a$ the early thirties of two alternative names proposed for the discipline, the longer 'economometrics' was rejected.

Since 1923 Frisch had been publishing already, first on some mathematicalstatistical problems, but soon on empirical research bascd on original ideas, such as the measurement of the flexibility of the marginal utility of income, based on the assumption that sugar constitutes an independent commodity (1932).

From 1931 on to the Second World War an Annual European metting of the Econometric Society was held, lasting three days. Informal as it was in these days, there were no presidents or secretaries; so le.ddership emerged spontaneously in this small highly motivated group and Ragnar Frisch was the leader and inspiror. We would discuss morning, afternoon and evening and often Frisch came along with a synthesis at the next breakfast, evidently worked out during the night. I for one always needed a rest, back home.

Frisch was the soul of the group, endowed with a unique teaching talent. His addresses and interventions were crystal clear, spoken slowly (unlike the French) and articulately (unlike the English) and so also reached the poor non-Frenchnon-English members - among whom were some outstanding Poles. Only a 
slight Scandinavian accent in pronouncing English 'book' as if it had been Norwegian 'but' (not 'bok') revealed his nationality.

Since the list of his publications has been published, at least up to 1969 , in the Swedish Journal of Economics, I will not try even to mention all his most important writings but only select some of the many subjects he covered. Wherever he touched a subject he added a remarkable contribution to it.

An early example of a purfect presentation is his article (1931, pp. 62 fi.) on land rent 'Einige Punkte einter Preistheorie mit Boden und Arbeit als Yroduktionsfaktoren' (Some points of a price theory with land and labour as productive factors).

I already sriefly mentionsd his endeavours to measure the flexibility of the marginal utility of income. In order to, eneralize his results he dropped the assumption of independence of the comriodity chosen as a basis. This forced him to use multiple correlations and measures for the reliabiiity of the regression coefficients and led him to find confidence intervals simply by comparing first, second etc. regression coefficients, shown in his 'bunch maps' (1934a).

He introduced the concept of dynamics in a more satisfactory way than most "literary" economists, excluding from its movements determined by exogenous variables, as in comparative statics.

He was the first economist to construct a model generating ti:n simu'ianecis endogenous cycles, whose periods, upon crude estimation of the corficients of the structural equations, are close to the American, 3 to 4 year, and the European cycle, around 7 years (1933). During the great depression he developed a proposal to stop the downward spiral by a sort of clearing house for purchases combined into closed circuits (1934b). After the war he proposed a similar mechanism to break out of the deacilock of non-convertibility of monies (1948).

A subject io which he contributed considerably was the theory of index numbers, stimulated by work by Staehie, Divisia ard Konüs. On several meetings of the Econometric Society the subject returned, usually enriched by some new ideas of Frisch's.

The work of most of us was, of course, interrupted by the Second World War and some of our friends never returned. Frisch experienced living in a concentration camp for some time.

For those of us who had come through it was an immense happiness to be together again in the first post-war European meeting, somewhere in the Alps and I thoroughly enjoyed listening to Frisch whose mind was more active than ever. In a brief article in Econometrica (1946) he stated, with clear satisfaction, that the demand for quantitatively thinking economists boomed and he formulated some of the responsibilities of this new work for post-war planning - an activity particularly require by the Norwe oian, the Batish, the French and the Dutch governments. Later, other countries followed as well as large business enterprises.

Ragnat Frisch also becane a member of one of the United Nations Com- 
mittees, the one for employment policies. Although this committee suffered from the too diverse backgrounds of their members and did not live long, we owe it a most important memorandum by Frisch (1949), in which the key irsas were set out which later became the corner stones of the theory of economic policy, with its distinction of four types of variables: target variables, instrument variables, data and 'other' variables, sometimes called irrelevant. In the pure theory of economics the unknowns are the target and the 'other' variables; in the theory of economic policy (or applied theory of economics) the instrument and the 'other' variables were the unknowns. Thus the main problem of economic policy could be seen as a 'partial inversion' of the main problem of 'explaining' economic change.

In the post-war period of Frisch's activity a fairly clear shift in his activities took place, common to some more of us, in that soon the main problem for him had become the problem of planning entire national economies, especially of developing countries. In a impressive series of memoranda of rapidly increasing volume and complication he developed what would later be called the Oslo Channel Model. Its hard core was an extended input-output model, where also the categories of national accounts were absorbed and particular attention was given to the dynamics of development. Especially the investment process $w^{\text {ith }}$ its gestation period and the ensuing differences between investment starting, investment in process and the termination of investment projects, were carefully analysed and some complications deriving from external effects and economies of scale elaborated (1962).

Among the basic apparatuses needed, Frisch had already before given attention to Pareto optima (1954) - cilrifying, in his masterly way, some essential features, such as the nezessity not to introduce in their definition ary prejudice on the social structure - and a new method of solving linear programming problems, called the multiplex method (1957).

His interest in the development planning problem brought him to India and Egypt, in both of which countries he stayed for a prolonged period. Apart from educating, in each of these countries, a group of young and thorough specialists, he also tried to explain to Nehru as well as to Nasser, how their political preferences had to be formulated so as to serve as the objective function of the planning problem. His experiences on these attempts were made the sub st of his speech to the Swedish Federation of Industries, a traditional corrolary to receiving the Nobel memorial prize for economics, which he was the first to receive in 1969.

Although it is difficult to imagine that Ragnar Frisch gave himself much time for relaxation, it was generally known that his major hobby was the observation of bees - but of course there is also a publication by him (1952) on an aspect of their behaviour.

In the last decade Frisch entered into politics by playing a leading role in the movement against Norway's joining the European Common Market. It must have been a reason for satisfaction to him that the referendum in fact rejected 
Norway's entrance - just as much as it was a reasun for regret to this author. Frisch's strong conviction was that his country had better remain an example of democracy and social justice rather than trying from inside the EEC to lift its democratic and social level. And who would not agree that Norwegians are strong on both counts!

Ragnar Frisch is no longer with us. But the forces he has awakened continue to live in his pupils and no chapter of economic is without a trace of his search for understanding it and using this understanding for the welfare of all.

\section{References}

R. Frisch, 1931, Einige Punkte einer Preistheori, mit Boden und Arbeit als Prolluktionsfaktoren, Zzitschrift für Nationalökonomie 3,62 ff.

R. Frisch, 1932, New methods of measuring marginal utility (Tübingen).

R. Frisch, 1933, Protsagation problems and impulse problems in dynamic economics, in: Economic essays in honor of Gustav Cassel (London) $387 \mathrm{ff}$.

R. Frisch, 1934a, Statistical confluence analysis by means of complete regression systems, Report no. 5 (Institute of Eccnomics, University of Oslo).

R. Frisch, 1934b, Circulation planning, Econometrica 2, $258 \mathrm{ff}$.

R. Frisch, 1946, The responsibility of the econometrician, Econometrica 14, $1 \mathrm{ff}$.

R. Frisch, 1948, The problem of multicompensatory trade, Outline of a system of multicompensatory trade. The Review of Economies and Statistics 30, p. $265 \mathrm{fr}$.

R. Frisch, 1949, A memorandum on price-wage-tax-subsidy policiess as instraments in maintaining eptimal employment (Institute of Economics, University of Oslo) published as a U.N. document E/C N1/Sub 2/13, April.

R. Frisch, 1952, Das Ausleseproblem in der Bienenzuichtung, Zeitschrift für Bienenforschung 1,9.

R. Frisch, 1954, La theorie de ìavantage collectif et les régions de Pareto, Economie Appliquée $7,211 \mathrm{fi}$.

R. Frisch, 1957, The mutiples method for linear programming, Sankyi $18,329 \mathrm{ff}$.

R. Frisch, 1959, A complete scheme for computing all direct and cross demand elasticities in a model with many sectors, Economatrica 27, $177 \mathrm{ff}$; and 1962, Preface to the Oslo Channel Model, Europe's future in figures (Amisterdam) $248 \mathrm{ff}$. 